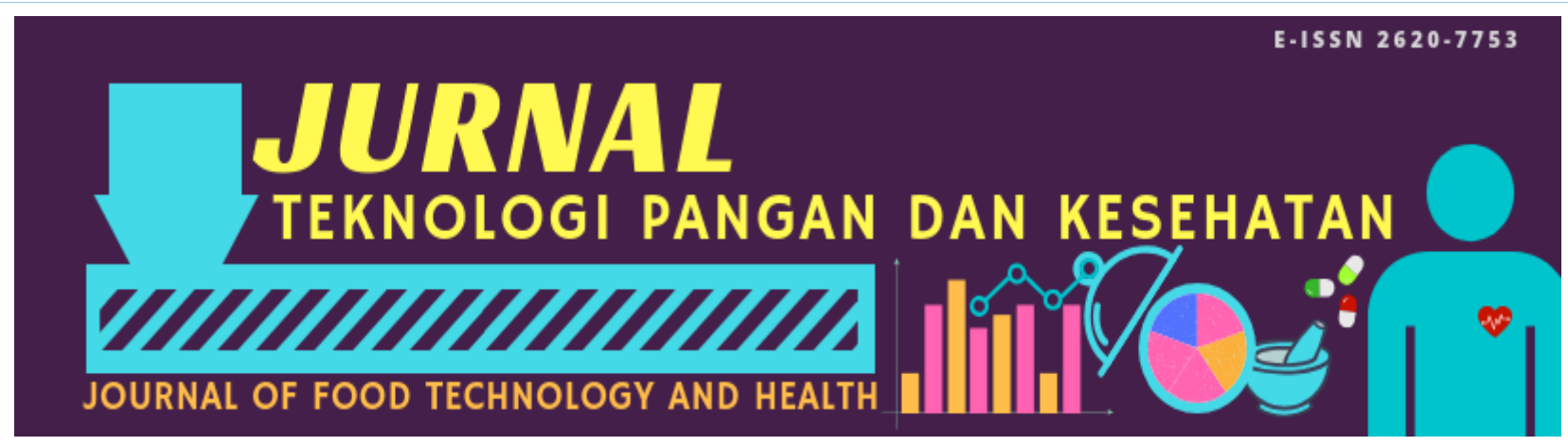

Volume I Nomor I Tahun 2019

Hasil Penelitian

Diterima 9 Agu 2018

Disetujui 29 Mei 2019

\title{
KARAKTERISTIK KUE SEMPRONG HASIL FORMULASI TEPUNG AMPAS KEDELAI (Glycine max L.)
}

\author{
Shanti Pujilestari*, Niken Larasati \\ Universitas Sahid, Jakarta
}

\begin{abstract}
ABSTRAK: Ampas kedelai merupakan produk samping pengolahan tahu atau susu kedelai yang masih mengandung protein $17.72 \%$ dan serat kasar sebesar 3.23\%. Pada umumnya kue semprong yang merupakan kudapan tradisional Indonesia yang dibuat dengan bahan utama tepung beras berbentuk corong panjang. Pemanfaatan ampas kedelai pada kue semprong dapat dilakukan untuk menghasilkan makanan kudapan tradisional yang sehat. Tujuan dari penelitian ini adalah untuk mengetahui pengaruh formulasi tepung beras dan tepung ampas kedelai yang berbeda (100:0, 90:10, 80:20, 70:30 dan 60:40) terhadap mutu kue semprong dan untuk memperoleh formulasi kue semprong terpilih. Penelitian eksperimen ini menggunakan Rancangan Acak Lengkap 5 perlakuan dengan 3x ulangan. Bila ada perbedaan, maka akan dilakukan uji lanjut Duncan. Hasil penelitian menunjukkan bahwa formulasi tepung beras dan tepung ampas kedelai yang berbeda menunjukkan terdapat perbedaan nyata pada kadar air, abu, protein, lemak, karbohidrat, serat kasar, warna, aroma, rasa dan tekstur $(\alpha=0.05$ dan $\alpha=0.01)$, tetapi berbeda tidak nyata pada kerenyahan semprong ( $\alpha=0.05)$. Kue semprong terpilih adalah kue semprong dengan formulasi tepung beras dan tepung ampas kedelai 80:20, dengan kerenyahan $1106.12 \mathrm{~g} / \mathrm{mm} 2$, kadar air 3.88\%, abu 1.90\%, protein $12.59 \%$, lemak $16.12 \%$, karbohidrat $64.06 \%$ dan serat kasar 4.21\%, warna coklat (2.4), aroma kedelai agak kuat (3.4), rasa agak manis (3.2) dan agak renyah (3.6). Kue semprong terpilih telah memenuhi Standar Nasional Indonesia (SNI) Nomor 2973-2011 untuk kadar air dan protein.
\end{abstract}

Kata Kunci: Karakteristik, tepung beras, ampas kedelai, semprong, tradisional

ABSTRACT: Soybean garbage is a byproducts in tofu or soybean milk manufacturer where still protein contains 17.72 and crude fiber 3.23\%. Semprong is traditional Indonesian snack food which have roll shaped and crispness. Generally semprong made from rice flour as the main ingredient. The utilization of soybean garbage on semprong cake can go to find a healthy traditional snack food. The aims of this research was to determine the influence of the varies formulation of rice flour and soybean garbage flour (100:0, 90:10, 80:20, 70:30 dan 60:40) to the quality of semprong snack, and to get the preference formulation. The experiment design in this research was completely randomized design with five formulations factor with three replicates. The result showed that the varies formulation of rice flour and soybean garbage had significant effect on moisture content, ash, protein, fat, carbohydrate, crude fiber, colour, flavor, taste and crispness on organoleptic but haven't significant effect on crispness of Physical test. The preference of semprong was formulation 80:20, with $1106.12 \mathrm{~g} / \mathrm{mm} 2 \mathrm{crispness}$, $3.88 \%$ moisture content, $1.90 \%$ ash, $12.59 \%$ protein, $16.12 \%$ fat, $64.06 \%$ carbohydrate, and $4.21 \%$ crude fiber. browning color (2.4), rather strong of soybean flavor (3.4), rather sweet taste (3.2) and rather crunchy (3.0). It characteristics had fulfilled in Indonesian National Standard (SNI) Number 2973-2011 on water and protein content.

Keywords: Characteristics, rice flour, soybean garbage, semprong, traditional

\section{PENDAHULUAN}

Ampas kedelai merupakan produk samping pengolahan tahu atau susu kedelai pada industri tahu dan susu kedelai. Industri tahu diketahui adalah industri yang dikelola oleh masyarakat begitu juga dengan industri

\footnotetext{
* Email korespondensi:

shanti_pujilestari@usahid.ac.id
} 
susu kedelai yang disebut juga sebagai industri rumah tangga. Ampas kedelai selama ini banyak digunakan sebagai pakan ternak, maka untuk meningkatkan nilainya ampas kedelai dimanfaatkan pada produk pangan.

Ampas kedelai yang diolah menjadi tepung masih mengandung gizi yang baik, yaitu protein sebesar $17.72 \%$, serta kandungan lainnya adalah serat kasar 3.23\% (Wati, 2013). Ampas kedelai ternyata masih mengandung zat-zat gizi, maka pemanfaatannya dapat dilakukan untuk meningkatkan kandungan gizi kue semprong.

Kue semprong dipilih karena kue semprong adalah salah satu jajanan tradisional Indonesia yang masih dikelola di tingkat rumahan. Hal ini setara dengan ampas kedelai yang juga dihasilkan oleh industri rumah tangga pada industri tahu dan susu kedelai. Kue semprong juga merupakan makanan jajanan yang digemari oleh masyarakat Indonesia. Sebagai makanan tradisional kue semprong ini tersebar di wilayah Indonesia antaranya di daerah Sumatra, Gorontalo, dan Jawa Timur dengan sebutan yang berbeda misalnya kue semprong disebut dengan nama opak gulung di daerah Blitar karena dibentuk dengan digulung-gulung.

Penelitian tentang pemanfaatan tepung ampas kedelai telah dilakukan sebelumnya pada beberapa produk misalnya sugar pastry, kue lidah kucing, dan bakso (Handarsari, (2010), Handarsari dan Syamsianah (2010) serta Wati (2013). Penelitian ini mendiversifikasi tepung ampas kedelai pada kue semprong. Semprong adalah jajanan olahan kering yang berbentuk gulungan memanjang. Pada umumnya kue semprong dibuat dengan bahan dasar tepung beras. Untuk membuat jajanan kering yang sehat, maka dilakukan penambahan tepung ampas kedelai yang dapat menambah nilai gizinya dengan mengembangkan produk tradisional dan memanfaatkan limbah.

Tepung beras yang banyak mengandung amilopektin yaitu $88.22 \%$ (Imanningsih, 2012) akan meningkatkan kerenyahan pada kue semprong (Supriyadi, 2012), tetapi dengan adanya penambahan tepung ampas kedelai maka tepung beras akan berkurang dalam formulasi, sehingga kerenyahan kue semprong dimungkinkan akan berkurang. Dengan demikian dibutuhkan penelitian untuk mengetahui formulasi yang paling baik dan disukai. Oleh karena itu penelitian formulasi tepung beras dan tepung ampas kedelai pada kue semprong yang diharapkan dapat meningkatkan kadar gizi kue semprong terutama kadar protein dan serat kasar kue semprong. Pada penelitian epidemologi menunjukkan perkembangan penyakit disebabkan karena rendahnya asupan serat (Kusharto, 2006).

\section{METODE PENELITIAN Bahan dan Alat}

Bahan utama yang digunakan dalam pembuatan kue semprong adalah tepung beras dan tepung ampas kedelai, ditambah dengan rumput laut, telur, gula pasir, santan, dan bubuk kayu manis.

Alat-alat utama yang digunakan dalam penelitian ini adalah mixer, saringan tepung 80 mesh, cetakan kue semprong, oven, desikator, timbangan analitik, tabung kjedahl, corong buchner, labu lemak, tanur, ekstraksi soxhlet, hot plate, tabung reaksi, penyaring vakum, dan Texture analyzer.

\section{Tahapan Penelitian}

Penelitian ini terdiri dari 2 (dua) tahap yaitu tahap penelitian pendahuluan dan utama. Penelitian pendahuluan diantaranya untuk mengetahui kandungan proksimat (air, abu, protein, lemak dan karbohidrat) serta kandungan serat kasar bahan utama kue semprong. Sedangkan penelitian utama dilakukan untuk mengetahui pengaruh formulasi tepung beras dan tepung ampas kedelai yang berbeda (100:0, 90:10, 80:20, 70:30 dan 60:40) terhadap mutu kue semprong dan untuk memperoleh formulasi kue semprong terpilih.

Metode yang digunakan dalam penelitian ini adalah Rancangan Acak Lengkap (RAL) satu faktor dengan 5 taraf dan 3 kali ulangan. Perlakuan pada penelitian ini adalah formulasi tepung beras dan tepung ampas kedelai 100:0, 90:10, 80:20, 70:30 dan 60:40. Parameter mutu kue semprong yang diamati yaitu mutu fisik (kerenyahan dengan AOAC 
(2006)), mutu kimia (kadar air, abu, protein, lemak, karbohidrat dan serat kasar dengan AOAC (2006)), dan mutu organoleptik (mutu hedonik dan hedonik terhadap warna, aroma, rasa, dan kerenyahan) serta kesukaan secara umum.

Sebagai pembanding mutu adalah Standar Nasional Indonesia (SNI) Nomor: 2973-2011 syarat mutu kue kering (Badan Standarisasi Nasional, 2011). Penelitian ini dilaksanakan di Laboratorium Teknologi Pangan Universitas Sahid Jakarta dan Laboratorium Anugrah Analisis Sempurna.

\section{Pembuatan Kue Semprong}

Bahan-bahan yang digunakan pada penelitian ini adalah tepung beras, tepung ampas kedelai, rumput laut, telur, gula pasir, santan dan bubuk kayu manis. Bahan-bahan lain dibeli di pasaran. Pembuatan tepung ampas kedelai mengacu pada penelitian Sulistiani (2004). Persentase masing-masing bahan tersebut dapat dilihat pada Tabel 1.

Tabel 1. Persentasi bahan untuk kue semprong

\begin{tabular}{lcc}
\hline \multicolumn{1}{c}{ Bahan } & $\begin{array}{c}\text { Jumlah } \\
\text { (gr) }\end{array}$ & $\begin{array}{c}\text { Persentase } \\
(\%)\end{array}$ \\
\hline $\begin{array}{l}\text { Tepung beras : } \\
\text { Tepung ampas }\end{array}$ & 100 & 23,26 \\
kedelai & & \\
Rumput laut & 30 & 6,98 \\
Telur & 78 & 18,14 \\
Gula pasir & 50 & 11,63 \\
Santan & 170 & 39,53 \\
Bubuk kayu manis & 2 & 0,46 \\
\hline \multicolumn{1}{c}{ Total } & 430 & 100 \\
\hline
\end{tabular}

Pembuatan kue semprong mengacu pada penelitian Hasan et al. (2014). Pertama dilakukan dengan mencampur telur dan gula pasir terlebih dahulu menggunakan mixer kecepatan tinggi selama 5 menit hingga adonan mengembang. Adonan ditambahkan rumput laut yang sudah dihaluskan dan santan, diaduk menggunakan mixer kecepatan sedang selama 3 menit sampai adonan merata. Ke dalam adonan ditambahkan bubuk kayu manis dan formulasi tepung beras dan tepung ampas kedelai, diaduk menggunakan mixer kecepatan sedang selama 3 menit hingga adonan tercampur merata. Proses berikutnya adalah pemanggangan dengan api langsung diatas cetakan kue semprong hingga berwarna kuning kecoklatan. Cetakan kue semprong terlebih dahulu dipanaskan dan diolesi dengan mentega selama 10 menit. Setelah panas, cetakan diangkat dari kompor, kemudian adonan sebanyak $10 \mathrm{ml}$ dituangkan dalam cetakan dan diratakan. Kedua sisi cetakan dikatupkan dan dipanaskan selama 2 menit dengan api kecil (suhu $100^{\circ} \mathrm{C}$ ) sambil dibolak-balik. Proses terakhir adalah pembentukkan kue semprong menjadi gulungan (roll).

\section{HASIL DAN PEMBAHASAN}

Penelitian pendahuluan dilakukan untuk mengetahui kandungan proksimat (kadar air, kadar abu, kadar protein, kadar lemak, dan kadar karbohidrat) serta kadar serat kasar dari bahan baku tepung beras dan tepung ampas kedelai sebagai bahan utama. Analisa proksimat dan kadar serat kasar dari bahan baku tepung beras dan tepung ampas kedelai yang digunakan dapat dilihat pada Tabel 2 .

Tabel 2. Hasil analisa proksimat dan serat kasar bahan utama

\begin{tabular}{ccc}
\hline \multirow{2}{*}{ Parameter } & \multicolumn{2}{c}{ Hasil Pengujian } \\
\cline { 2 - 3 } & $\begin{array}{c}\text { Tepung } \\
\text { beras }\end{array}$ & $\begin{array}{c}\text { Tepung ampas } \\
\text { kedelai }\end{array}$ \\
\hline Air & $13.74 \%$ & $16.54 \%$ \\
Abu & $0.48 \%$ & $6.30 \%$ \\
Protein & $7.86 \%$ & $15.23 \%$ \\
Lemak & $0.11 \%$ & $6.59 \%$ \\
Karbohidrat & $77.80 \%$ & $55.49 \%$ \\
Serat Kasar & $3.21 \%$ & $3.33 \%$ \\
\hline
\end{tabular}

Tabel 2 menunjukkan bahwa tepung ampas kedelai yang digunakan masih mengandung protein sebesar $15.23 \%$ dan serat kasar $3.33 \%$. Tepung beras yang digunakan dalam penelitian ini mengandung protein $7.86 \%$ dan serat kasar $3.21 \%$. Karbohidrat tepung beras lebih besar dari tepung ampas kedelai, yaitu $77.80 \%$, sedangkan kandungan karbohidrat tepung ampas kedelai yaitu 55.49\%. Kadar air, abu, lemak tepung beras lebih rendah dari tepung ampas kedelai. 
Tabel 3. Nilai kerenyahan kue semprong dengan formulasi tepung beras dan tepung ampas kedelai yang berbeda

Formulasi tepung beras dan tepung ampas kedelai pada kerenyahan kue semprong

\begin{tabular}{cccccc}
\cline { 2 - 5 } Kerenyahan & $100: 0$ & $90: 10$ & $80: 20$ & $70: 30$ & $60: 40$ \\
\cline { 2 - 5 } & $1120.31 \pm 66.60$ & $1109.79 \pm 41.35$ & $1106.12 \pm 63.23$ & $1105.02 \pm 63.95$ & $1087.66 \pm 7.66$ \\
\hline
\end{tabular}

\section{Mutu fisik (kerenyahan) kue semprong}

Nilai rata-rata kerenyahan kue semprong dengan formulasi tepung beras dan tepung ampas kedelai yang berbeda dapat dilihat pada Tabel 3.

Kue semprong dengan formulasi tepung beras dan tepung ampas kedelai yang berbeda (100:0, 90:10,80:20, 70:30, dan 60:40) relatif sama. Berdasarkan hasil sidik ragam, diperoleh nilai signifikansi lebih besar dari $\alpha=0.05$, dengan demikian formulasi tepung beras dan tepung ampas kedelai yang berbeda $(100: 0,90: 10,80: 20,70: 30$, dan 60:40) tidak memengaruhi nilai kerenyahan kue semprong. Hal ini diduga bahwa tepung ampas kedelai tidak memiliki zat seperti gluten pada terigu, pati pada tapioka, dan amilopektin pada tepung ketan sehingga tidak memiliki kapasitas gelatinisasi sehingga menyebabkan adonan tidak mengembang (Yustina dan Abadi, 2012). Tepung beras juga memiliki nilai viskositas tinggi pada fase setback, sehingga memerlukan pemasakan yang cukup lama untuk memberikan kekentalan yang baik pada produk yang memerlukan kekentalan setelah masak (Imanningsih, 2012).

\section{Mutu kimia kue semprong}

Mutu kimia kue semprong adalah nilai rata-rata proximat dan serat kasar kue semprong dengan formulasi tepung beras dan tepung ampas kedelai yang berbeda dapat dilihat pada Tabel 4 .

Tabel 4. Nilai rata-rata mutu kimia kue semprong dengan formulasi tepung beras dan tepung ampas kedelai yang berbeda

\begin{tabular}{cccccc}
\hline \multirow{2}{*}{ Parameter } & \multicolumn{5}{c}{ Formulasi tepung beras dan tepung ampas kedelai } \\
pada kue semprong \\
\cline { 2 - 6 } & $100: 0$ & $90: 10$ & $80: 20$ & $70: 30$ & $60: 40$ \\
\hline Air & $3.34 \pm 0.08^{\mathrm{a}}$ & $3.35 \pm 0.20^{\mathrm{a}}$ & $3.88 \pm 0.41^{\mathrm{ab}}$ & $3.95 \pm 0.33^{\mathrm{ab}}$ & $4.45 \pm 0.29^{\mathrm{b}}$ \\
Abu & $1.60 \pm 0.07^{\mathrm{a}}$ & $1.64 \pm 0.08^{\mathrm{a}}$ & $1.90 \pm 0.04^{\mathrm{ab}}$ & $2.15 \pm 0.09^{\mathrm{b}}$ & $1.83 \pm 0.31^{\mathrm{ab}}$ \\
Protein & $10.37 \pm 0.14^{\mathrm{a}}$ & $11.39 \pm 0.27^{\mathrm{b}}$ & $12.59 \pm 0.19^{\mathrm{c}}$ & $14.76 \pm 0.02^{\mathrm{d}}$ & $15.50 \pm 0.21^{\mathrm{e}}$ \\
Lemak & $16.41 \pm 0.05^{\mathrm{a}}$ & $19.35 \pm 0.13^{\mathrm{b}}$ & $16.12 \pm 0.13^{\mathrm{a}}$ & $17.34 \pm 0.08^{\mathrm{c}}$ & $17.68 \pm 0.10^{\mathrm{d}}$ \\
Karbohidrat & $68.28 \pm 0.40^{\mathrm{d}}$ & $65.34 \pm 0.52^{\mathrm{c}}$ & $64.06 \pm 0.82^{\mathrm{bc}}$ & $62.42 \pm 0.13^{\mathrm{b}}$ & $60.06 \pm 0.62^{\mathrm{a}}$ \\
Serat kasar & $3.27 \pm 0.06^{\mathrm{a}}$ & $3.45 \pm 0.16^{\mathrm{a}}$ & $4.21 \pm 0.11^{\mathrm{b}}$ & $4.25 \pm 0.12^{\mathrm{b}}$ & $4.38 \pm 0.13^{\mathrm{b}}$
\end{tabular}

Keterangan : Angka yang diikuti dengan huruf superscript berbeda (a, b, c, d, e) menunjukkan berbeda nyata $(\alpha=0.05$ atau $\alpha=0.01)$.

\section{Kadar air}

Formulasi tepung beras dan tepung ampas kedelai memengaruhi kadar air kue semprong $(\alpha=0.05)$. Semakin meningkatnya konsentrasi tepung ampas kedelai yang digunakan pada formulasi tepung beras dan tepung ampas kedelai maka kadar air kue semprong semakin meningkat. Hal ini diduga karena tepung ampas kedelai memiliki kadar air lebih tinggi dari tepung beras, yaitu sebesar $16.54 \%$ sedangkan tepung ampas kedelai memiliki kadar air $13.74 \%$. Kadar air kue semprong berada pada kisaran 3.34 4.45\% sehingga memenuhi syarat mutu kue kering SNI 01-2973-2011, yaitu kadar air maksimum 5\%. 


\section{Kadar abu}

Formulasi tepung beras dan tepung ampas kedelai memengaruhi kadar abu kue semprong $(\alpha=0.05)$. Semakin meningkatnya konsentrasi tepung ampas kedelai yang digunakan pada formulasi tepung beras dan tepung ampas kedelai maka kadar abu kue semprong semakin meningkat. Hal ini diduga karena tepung ampas kedelai memiliki kadar abu lebih tinggi dari pada kadar abu tepung beras, yaitu sebesar $6.30 \%$ sedangkan kadar abu tepung beras sebesar $0.48 \%$. Kadar abu yang diperoleh kue semprong berada di kisaran 1.60-2.15\%, tetapi tidak bisa dibandingkan dengan syarat mutu kue kering pada SNI 2973-2011 karena pada SNI tersebut tidak menetapkan syarat mutu untuk kadar abu.

\section{Kadar protein}

Formulasi tepung beras dan tepung ampas kedelai memengaruhi kadar protein kue semprong $(\alpha=0.01)$. Semakin meningkatnya konsentrasi tepung ampas kedelai yang digunakan pada formulasi tepung beras dan tepung ampas kedelai maka kadar protein pada kue semprong semakin meningkat. Hal ini diduga karena tepung ampas kedelai memiliki kadar protein lebih tinggi dibandingkan dengan tepung beras yaitu sebesar $15.23 \%$, sedangkan tepung beras memiliki kadar protein sebesar 7.86\%. Hal ini sejalan dengan penelitian Handarsari dan Syamsianah (2010), pada penelitian bakso dengan menggunakan ampas kedelai. Pada penelitian ini juga didapatkan bahwa semakin tinggi ampas kedelai maka protein bakso semakin meningkat, demikian juga yang terjadi pada penelitian sugar pastry (Handarsari, 2010). Kadar protein kue semprong berada pada kisaran 10.37 $15.50 \%$ sehingga memenuhi syarat mutu kue kering SNI 01-2973-2011 yaitu kadar protein minimal 5\%.

\section{Kadar lemak}

Formulasi tepung beras dan tepung ampas kedelai memengaruhi kadar lemak kue semprong $(\alpha=0.01)$. Semakin meningkatnya konsentrasi tepung ampas kedelai yang digunakan pada formulasi tepung beras dan tepung ampas kedelai maka kadar lemak pada kue semprong semakin meningkat. Hal ini diduga karena tepung ampas kedelai memiliki kadar lemak lebih tinggi dari tepung beras yaitu sebesar 6.59\%, sedangkan kadar lemak tepung beras sebesar $0.11 \%$. Kadar lemak yang diperoleh pada kue semprong berada di kisaran 16.41 - 19.35, tetapi tidak bisa dibandingkan dengan syarat mutu kue kering pada SNI 2973-2011 karena pada SNI tersebut tidak menetapkan syarat mutu untuk kadar lemak.

\section{Kadar karbohidrat}

Formulasi tepung beras dan tepung ampas kedelai memengaruhi kadar karbohidrat kue semprong $(\alpha=0.01)$. Semakin meningkatnya konsentrasi tepung ampas kedelai yang digunakan pada formulasi tepung beras dan tepung ampas kedelai maka kadar karbohidrat kue semprong semakin menurun. Hal ini diduga karena tepung ampas kedelai memiliki kadar karbohidrat lebih rendah dari tepung beras yaitu sebesar $55.49 \%$, sedangkan tepung beras memiliki kadar karbohidrat sebesar 77.80\%. Kadar karbohidrat yang diperoleh kue semprong berkisar 60.06 - 68.28\%, tetapi tidak bisa dibandingkan dengan persyaratan mutu kue kering pada SNI 2973-2011 karena pada SNI tersebut tidak menetapkan syarat mutu untuk kadar karbohidrat.

\section{Kadar serat kasar}

Formulasi tepung beras dan tepung ampas kedelai memengaruhi kadar serat kasar kue semprong $(\alpha=0.05)$. Semakin meningkatnya konsentrasi tepung ampas kedelai yang digunakan pada formulasi tepung beras dan tepung ampas kedelai maka kadar serat kasar pada kue semprong semakin meningkat. Hal ini diduga karena tepung ampas kedelai memiliki kadar serat kasar lebih besar dari tepung beras yaitu sebesar 3.33\%. Sedangkan tepung beras memiliki kadar serat kasar sebesar 3.21\%. Kadar serat kasar yang diperoleh pada kue semprong berkisar antara 3.27 - 4.38, tetapi tidak bisa dibandingkan dengan syarat mutu kue kering SNI 2973-2011 tidak ditetapkan syarat mutu untuk kadar serat kasar. 


\section{Mutu Organoleptik Kue Semprong Mutu hedonik}

Nilai rata-rata mutu hedonik kue semprong dengan formulasi tepung beras dan tepung ampas kedelai yang berbeda dapat dilihat pada Tabel 5.

\section{Warna}

Formulasi tepung beras dan tepung ampas kedelai memengaruhi warna kue semprong $(\alpha=0.05)$. Semakin meningkatnya konsentrasi tepung ampas kedelai yang digunakan pada formulasi tepung beras dan tepung ampas kedelai maka warna kue semprong yang dihasilkan akan semakin gelap atau coklat. Hal ini diduga perbedaan warna yang dihasilkan disebabkan oleh reaksi maillard yang terjadi selama proses pemasakan. Reaksi maillard adalah reaksi antra gugus karbonil dari gula pereduksi dan gugus amino bebas, peptida, atau protein dengan adanya pemanasan. Reaksi maillard menghasilkan warna coklat, sehingga termasuk kedalam reaksi pencoklatan enzimatis (Estiasih, et al., 2016). Menurut Fellows (2005), warna coklat ini diasosiasikan akibat adanya reaksi maillard antara gula pereduksi dan gugus amino, karamelisasi gula dan dextrin sehingga membentuk warna kecoklatan. Selain itu warna yang dihasilkan oleh kue semprong juga dipengaruhi oleh adanya bubuk kayu manis yang berwarna coklat. Hal ini juga terjadi pada penelitian kue kering lidah kucing, semakin banyak semakin coklat (Wati, 2013). Pada penelitian lain Handarsari (2010) dengan pemanfaatan tepung ampas kedelai dalam pembuatan sugar pastry pada menunjukkan hasil organoleptik terhadap warna produk yang menurun seiring dengan meningkatnya penambahan tepung ampas kedelai.

Tabel 5. Nilai rata-rata mutu hedonik kue semprong dengan formulasi tepung beras dan tepung ampas kedelai yang berbeda

\begin{tabular}{|c|c|c|c|c|c|}
\hline \multirow{2}{*}{\multicolumn{2}{|c|}{$\begin{array}{l}\text { Formulasi tepung beras dan } \\
\text { tepung ampas kedelai }\end{array}$}} & \multicolumn{4}{|c|}{ Parameter mutu } \\
\hline & & Warna & Aroma & Rasa & Kerenyahan \\
\hline & $100: 0$ & $2.9^{\mathrm{b}}$ & $3.5^{c}$ & $3.3^{\mathrm{bc}}$ & $4.0^{\mathrm{d}}$ \\
\hline & $90: 10$ & $3.2^{c}$ & $3.5^{b}$ & $3.4^{b}$ & $3.4^{c}$ \\
\hline & $80: 20$ & $2.4^{\mathrm{a}}$ & $3.3^{b}$ & $3.4^{\mathrm{cd}}$ & $3.6^{c}$ \\
\hline & $70: 30$ & $2.4^{\mathrm{a}}$ & $3.4^{c}$ & $3.2^{\mathrm{d}}$ & $3.0^{\mathrm{b}}$ \\
\hline & $60: 40$ & $2.8^{b}$ & $2.9^{\mathrm{a}}$ & $3.0^{\mathrm{a}}$ & $2.3^{\mathrm{a}}$ \\
\hline \multicolumn{6}{|l|}{ Keterangan } \\
\hline Warna & \multicolumn{5}{|c|}{$\begin{array}{l}5 \text { (kuning), } 4 \text { (agak kuning kecoklatan), } 3 \text { (kuning kecoklatan), } 2 \text { (coklat), } 1 \text { (sangat } \\
\text { coklat) }\end{array}$} \\
\hline Aroma & \multicolumn{5}{|c|}{ : 5 (sangat kuat), 4 (kuat), 3 (agak kuat), 2 (tidak kuat), 1 (sangat tidak kuat) } \\
\hline Rasa & \multicolumn{5}{|c|}{ : 5 (sangat manis), 4 (manis), 3 (agak manis), 2 (tidak manis), 1 (sangat tidak manis) } \\
\hline Tekstur & \multicolumn{5}{|c|}{$\begin{array}{l}5 \text { (sangat renyah), } 4 \text { (renyah), } 3 \text { (agak renyah), } 2 \text { (tidak renyah), } 1 \text { (sangat tidak } \\
\text { renyah) }\end{array}$} \\
\hline
\end{tabular}

\section{Aroma}

Formulasi tepung beras dan tepung ampas kedelai memengaruhi aroma kue semprong $(\alpha=0.05) . \quad$ Semakin meningkatnya konsentrasi tepung ampas kedelai yang digunakan pada formulasi tepung beras dan tepung ampas kedelai maka aroma kedelai pada kue semprong semakin menurun. Hal ini diduga karena bahan baku bubuk kayu manis yang ada pada formula dasar memiliki aroma yang sangat kuat sehingga menutupi aroma kedelai pada kue semprong yang menyebabkan aroma kedelai pada kue semprong sulit untuk diidentifikasi. Pada penelitian Handarsari (2010), penilaian terhadap rasa dan aroma yang khas dari ampas kedelai tidak terasa pada sugar pastry dengan substitusi tepung ampas kedelai. Hal ini disebabkan bahwa proses pembuatan sugar pastry dibuat dengan mencampur tepung ampas kedelai yang proses pembuatannya melalui pengukusan terlebih 
dahulu, tujuan pengukusan adalah untuk menginaktifkan enzim lipogsigenase yang menyebabkan aroma tidak enak dan dapat meminimalkan aroma langu dari ampas kedelai.

\section{Rasa}

Formulasi tepung beras dan tepung ampas kedelai memengaruhi rasa kue semprong $(\alpha=0.05)$. Semakin meningkatnya konsentrasi tepung ampas kedelai yang digunakan pada formulasi tepung beras dan tepung ampas kedelai maka rasa pada kue semprong semakin manis. Hal ini diduga karena bahan baku lainnya seperti gula pasir yang ada pada formula dasar berperan sebagai variabel terkontrol yang jumlahnya tetap pada setiap perlakuan. Rasa dinilai dengan adanya tanggapan rangsangan kimiawi oleh indera dan saraf trigeminal yang terletak di rongga mulut pencicip yaitu lidah dan hidung, kepekaan terhadap rasa bervariasi tergantung dari substansi yang diuji, serta keadaan panelis dan suhu (Setyaningsih, 2010).

\section{Kerenyahan}

Formulasi tepung beras dan tepung ampas kedelai memengaruhi kerenyahan kue semprong $(\alpha=0.05)$. Semakin meningkatnya konsentrasi tepung ampas kedelai yang digunakan pada formulasi tepung beras dan tepung ampas kedelai maka kerenyahan pada kue semprong semakin menurun. Hal ini diduga karena penambahan jenis dan jumlah bahan pengisi yang digunakan dalam pembuatan kue kering memengaruhi mutu fisik (kerenyahan) dari kue kering tersebut (Sianipar, 2003).

Semakin rendah kadar air akan menghasilkan struktur yang rapuh dan porus pada kue kering sehingga kerenyahannya meningkat. Kadar air yang semakin tinggi pada kue kering akan membentuk struktur plastis pada produk sehingga sulit patah (Bowen, 2006). Data kadar air pada penelitian ini menunjukkan peningkatan ketika tepung ampas kedelainya bertambah, sehingga sudah semestinya kerenyahannya menurun.
Kerenyahan pada produk kue kering juga dipengaruhi oleh protein, karena kue semprong ini mengandung tepung ampas kedelai yang mengandung protein sebesar 15.23\%. Data pada penelitian ini menunjukkan bahwa semakin banyaknya konsentrasi tepung ampas kedelai pada formulasi maka semakin tinggi protein kue semprong, sehingga kerenyahannya semakin menurun. Menurut Harper (2004), protein akan membentuk suatu lapisan pada permukaan granula pati. Protein yang mengalami proses pemanasan akan mengalami denaturasi protein sehingga struktur kue kering menjadi padat, kandungan airnya semakin tinggi, serta kurang porus. Semakin tinggi kandungan protein yang terkandung pada kue semprong maka strukturnya semakin padat dan nilai kerenyahannya berkurang. Sebaliknya bila semakin rendah kandungan protein yang terkandung pada kue semprong maka strukturnya semakin porus dan nilai kerenyahannya akan meningkat.

\section{Hedonik}

Nilai rata-rata hedonik kue semprong dengan formulasi tepung beras dan tepung ampas kedelai yang berbeda dapat dilihat pada Tabel 6 .

\section{Hedonik warna}

Formulasi tepung beras dan tepung ampas kedelai memengaruhi kesukaan warna kue semprong $(\alpha=0.05)$. Semakin meningkatnya konsentrasi tepung ampas kedelai yang digunakan pada formulasi tepung beras dan tepung ampas kedelai maka tingkat kesukaan panelis terhadap warna kue semprong semakin menurun. Hal ini menunjukkan bahwa semakin gelap atau coklat kue semprong maka kesukaan terhadap warna juga menurun.

\section{Hedonik aroma}

Formulasi tepung beras dan tepung ampas kedelai memengaruhi kesukaan aroma kue semprong $(\alpha=0.05)$. Semakin meningkatnya konsentrasi tepung ampas kedelai yang digunakan pada formulasi tepung beras dan tepung ampas kedelai maka tingkat kesukaan 
terhadap aroma kue semprong semakin menurun. Hal ini setara dengan penelitian lain yaitu penambahan tepung ampas kedelai untuk sugar pastry (Handarsari, 2010) menunjukkan kesukaan terhadap aroma produk akhir yang menurun seiring dengan meningkatnya penambahan tepung ampas kedelai. Data penelitian mutu hedonik menunjukkan bahwa menurunnya aroma kedelai maka semakin turun kesukaan panelis.

Tabel 6. Nilai rata-rata hedonik kue semprong dengan formulasi tepung beras dan tepung ampas kedelai yang berbeda

\begin{tabular}{cccccc}
\hline $\begin{array}{c}\text { Formulasi tepung beras dan } \\
\text { tepung ampas kedelai }\end{array}$ & Warna & Aroma & Rasa & Tekstur & $\begin{array}{c}\text { Kesukaan secara } \\
\text { umum }\end{array}$ \\
\hline $100: 0$ & $3.9^{\mathrm{c}}$ & $3.9^{\mathrm{c}}$ & $3.6^{\mathrm{b}}$ & $3.9^{\mathrm{d}}$ & $3.7^{\mathrm{c}}$ \\
$90: 10$ & $3.6^{\mathrm{b}}$ & $3.7^{\mathrm{bc}}$ & $3.5^{\mathrm{b}}$ & $3.4^{\mathrm{c}}$ & $3.5^{\mathrm{c}}$ \\
$80: 20$ & $3.6^{\mathrm{b}}$ & $3.8^{\mathrm{bc}}$ & $3.5^{\mathrm{b}}$ & $3.5^{\mathrm{c}}$ & $3.7^{\mathrm{c}}$ \\
$70: 30$ & $3.5^{\mathrm{b}}$ & $3.7^{\mathrm{b}}$ & $3.4^{\mathrm{b}}$ & $3.1^{\mathrm{b}}$ & $3.2^{\mathrm{b}}$ \\
$60: 40$ & $3.3^{\mathrm{a}}$ & $2.8^{\mathrm{a}}$ & $2.8^{\mathrm{a}}$ & $2.2^{\mathrm{a}}$ & $2.5^{\mathrm{a}}$ \\
\hline
\end{tabular}

Keterangan :

Tingkat kesukaan : 5 (sangat suka), 4 (suka), 3 (agak suka), 2 (tidak suka), 1 (sangat tidak suka) Angka yang diikuti dengan huruf superscript berbeda $(a, b, c, d, e)$ menunjukkan berbeda nyata $(\alpha=$ 0.05).

\section{Hedonik rasa}

Formulasi tepung beras dan tepung ampas kedelai memengaruhi kesukaan rasa kue semprong $(\alpha=0.05)$. Semakin meningkatnya konsentrasi tepung ampas kedelai yang digunakan pada formulasi tepung beras dan tepung ampas kedelai maka tingkat kesukaan terhadap rasa kue semprong semakin menurun. Pada penelitian lain dengan pemanfaatan tepung ampas kedelai untuk pembuatan sugar pastry (Handarsari, 2010) menunjukkan hasil organoleptik terhadap rasa produk akhir yang menurun seiring dengan meningkatnya penambahan tepung ampas kedelai. Data mutu hedonik menunjukkan bahwa semakin manis rasa kue semprong maka semakin meningkat kesukaan panelis.

\section{Hedonik kerenyahan}

Formulasi tepung beras dan tepung ampas kedelai memengaruhi kesukaan kerenyahan kue semprong $(\alpha=0.05)$. Semakin meningkatnya konsentrasi tepung ampas kedelai yang digunakan pada formulasi tepung beras dan tepung ampas kedelai maka tingkat kesukaan terhadap kerenyahan kue semprong semakin menurun. Pada penelitian lain dengan pemanfaatan tepung ampas kedelai untuk pembuatan sugar pastry (Handarsari, 2010) menunjukkan tingkat kesukaan tekstur menurun seiring dengan meningkatnya penambahan tepung ampas kedelai. Data penelitian mutu hedonik menunjukkan bahwa semakin tidak renyah maka semakin turun tingkat kesukaan. Walaupun pada penelitian ini pada parameter tekstur dengan menggunakan texture analyser tidak terjadi penurunan kerenyahan yang signifikan dengan bertambahnya tepung ampas kedelai.

\section{Hedonik kesukaan secara umum}

Formulasi tepung beras dan tepung ampas kedelai memengaruhi kesukaan umum kue semprong $(\alpha=0.05)$. Semakin meningkatnya konsentrasi tepung ampas kedelai yang digunakan pada formulasi tepung beras dan tepung ampas kedelai maka tingkat kesukaan secara umum pada kue semprong semakin menurun. Hasil penelitian ini sama dengan penelitian Wati (2013), pada subsitusi tepung ampas kedelai dalam pembuatan kue kering lidah kucing menunjukkan hasil kesukaan secara umum pada produk akhir yang menurun seiring dengan meningkatnya penambahan tepung ampas kedelai.

\section{Penentuan Formula Terbaik}

Pemilihan formulasi terbaik pada penelitian ini berdasarkan hasil hedonik terhadap kesukaan secara umum. Formulasi 
terpilih pada penelitian ini yaitu kue semprong dengan perbandingan tepung beras dan tepung ampas kedelai 80:20. Hal ini didasarkan pada uji Duncan hedonik kesukaan secara umum pada kue semprong dengan formulasi tepung beras dan tepung ampas kedelai dengan perbandingan 100:0 tidak berbeda nyata dengan formulasi 90:10 dan 80:20. Karakteristik kue semprong rumput laut dengan kue semprong formulasi tepung beras dan tepung ampas kedelai 80:20 dapat dilihat pada Tabel 7 .

Tabel 7. Karakteristik kue semprong rumput laut dengan kue semprong formulasi tepung beras dan tepung ampas kedelai

\begin{tabular}{ccc}
\hline & \multicolumn{2}{c}{ Karakteristik } \\
\cline { 2 - 3 } Parameter & $\begin{array}{c}\text { Kue semprong rumput laut } \\
\text { penelitian Hasan, et al. }(2014)\end{array}$ & $\begin{array}{c}\text { Kue semprong formulasi tepung } \\
\text { beras dan tepung ampas kedelai }\end{array}$ \\
& Tidak diukur & $1106.12 \mathrm{~g} / \mathrm{mm}^{2}$ \\
Kerenyaham & $3.03 \%$ & $3.88 \%$ \\
Air & $0.32 \%$ & $1.90 \%$ \\
Abu & $9.23 \%$ & $12.59 \%$ \\
Protein & $8.05 \%$ & $16.12 \%$ \\
Lemak & $75.19 \%$ & $64.06 \%$ \\
Karbohidrat & $1.15 \%$ & $4.21 \%$ \\
Serat Kasar & Tidak diukur & $3.7(\mathrm{suka})$ \\
Kesukaan secara & & \\
umum & &
\end{tabular}

Tabel 7 menunjukkan kue semprong dengan formulasi tepung beras dan tepung ampas kedelai mengandung protein $12.59 \%$ dan serat kasar 4.21\%. Protein kue semprong rumput laut (9.23\%) dari penelitian Hasan et al. (2014) cenderung lebih rendah dari kue semprong formulasi tepung beras dan tepung ampas kedelai hasil penelitian ini (12.59\%). Hal yang sama juga pada serat kasar yaitu kue semprong rumput laut (1.15\%) penelitian Hasan et al. (2014) cenderung lebih rendah dari kue semprong formulasi tepung beras dan tepung ampas kedelai hasil penelitian ini (4.21). Hal ini diduga karena penggunaan ampas kedelai yang masih mengandung protein $15.23 \%$ dan serat kasar $3.33 \%$.

Pemenuhan zat gizi pada kue semprong, diantaranya yaitu 1 (satu) semprong terpilih dapat menyumbang 1.24 gram/hari atau $2.38 \%$ dari kebutuhan protein per hari. Konsumsi 1 (satu) buah semprong terpilih dapat menyumbang 0.42 gram/hari atau $1.68 \%$ dari kebutuhan serat per hari.

\section{KESIMPULAN}

Formulasi tepung beras dan tepung ampas kedelai yang berbeda (100:0, 90:10, 80:20, 70:30, dan 60:40) memengaruhi mutu kimia (kadar air, kadar abu, kadar protein, kadar lemak, kadar karbohidrat dan kadar serat kasar), mutu organoleptik (mutu hedonik dan hedonik warna, aroma, rasa, tekstur dan kesukaan secara umum $) \quad(\alpha=0.05$ atau $\alpha=0.01)$. Tetapi formulasi tepung beras dan tepung ampas kedelai yang berbeda (100:0, 90:10, 80:20, 70:30, dan 60:40) tidak memengaruhi mutu fisik (kerenyahan) kue semprong $(\alpha=0.05)$.

Berdasarkan uji hedonik kesukaan secara umum pada kue semprong dengan formulasi tepung beras dan tepung ampas kedelai yang berbeda (100:0, 90:10, 80:20, 70:30, dan 60:40) diperoleh formulasi terpilih yaitu kue semprong dengan formulasi 80:20. Karakteristik kue semprong tersebut yaitu mutu fisik berupa nilai kerenyahan 1106.12 $\mathrm{g} / \mathrm{mm}^{2}$, mutu kimia berupa kadar air sebesar $3.88 \%$, kadar abu $1.90 \%$, kadar protein $12.59 \%$, kadar lemak 16.12\%, kadar karbohidrat $64.06 \%$, dan kadar serat kasar $4.21 \%$, mutu organoleptik berupa mutu hedonik warna dengan skor 2.4 (coklat), aroma kedelai dengan skor 3.4 (agak kuat), rasa dengan skor 3.4 (agak manis) dan 
kerenyahan dengan skor 3.0 (agak renyah) dan uji hedonik terhadap kesukaan secara umum dengan skor 3.7 (suka).

\section{DAFTAR PUSTAKA}

AOAC. 2006. Official Method of Analysis of the Assosiation Analytical Chemistry. Inc. Washington DC.

Bowen, R., 2006. Dietary Polysaccharides: Structure and Digestion. Diakses di www.vivo.colostate.edu/hbooks/pathphy s/digestion/basic/polysac.html. diakses tanggal 23 Januari 2016.

Badan Standarisasi Nasional (BSN). 2011. Standar Nasional Indonesia (SNI) Standar Mutu Kue kering Nomor: 01-2973-2011. BSN, Jakarta.

Estiasih, T., Harijono, E., Waziiroh, \& Fibrianto, K., 2016. Kimia dan Fisik Pangan. Jilid 1. Bumi Aksara. Jakarta.

Fellows, P.J., 2005. Food Processing Technology. CRC Press. Boca Raton. Florida.

Handarsari, E., 2010. Eksperimen Pembuatan Sugar Pastry dengan Substitusi Tepung Ampas Kedelai. Jurnal Pangan dan Gizi, 1(1), hal. 35-42.

Handarsari, E., \& Syamsianah, A., 2010. Analisis Kadar Zat Gizi, Uji Cemaran Logam dan Organoleptik pada Bakso Subsitusi Ampas Tahu. Prosiding Seminar Nasional Vol.2 No.1 Kesehatan Masyarakat, Olah Raga, Gizi dan Pangan. Universitas Muhammadiyah Semarang.

Harper, J.M., 2004. Extrusion of Food, 11. CRC Press. Boca Raton, Florida.

Hasan, L., Yusuf, N., \& Mile, L., 2014. Pengaruh Penambahan Kappaphycus alvarezii terhadap Karakteristik Organoleptik dan Kimiawi Kue Tradisional Semprong. Jurnal Ilmiah Perikanan dan Kelautan 2(3), hal. 107-114.

Imanningsih, N., 2012. Profil Gelatinisasi Beberapa Formulasi Tepung-Tepungan untuk Pendugaan Sifat Pemasakan. Penelitian Gizi Makanan, 35(1), hal. 13-22.

Kusharto, C.M., 2006. Serat Makanan dan Peranannya bagi Kesehatan. Jurnal Gizi dan Pangan, 2(1), hal. 45-54.

Setyaningsih, 2010. Analisis Sensori untuk Industri pangan dan Agro. Penerbit IPB Press, Bogor.

Sianipar, D.P., 2003. Meningkatkan mutu cookies. Tesis. Program Pascasarjana, Institut Pertanian Bogor, Bogor.

Sulistiani, 2004. Pemanfaatan ampas tahu dalam pembuatan tepung tinggi serat dan protein sebagai alternative bahan baku pangan fungsional. Skripsi. Jurusan Gizi Masyarakat dan Sumberdaya Keluarga. Institut Pertanian Bogor, Bogor.

Supriyadi, 2012. Studi Pengaruh AmilosaAmilopektin dan Kadar Air terhadap Kerenyahan dan Kekerasan Model Produk Gorengan. Skripsi. Fakultas Teknologi Pertanian. Institut Pertanian Bogor, Bogor.

Wati, R., 2013. Pengaruh substitusi tepung ampas tahu sebagai bahan komposit terhadap kuallitas kue kering lidah kucing. Food Science and Culinary Education Journal, 1(2), hal. 57-62.

Yustina, I., \& Abadi, F.R., 2012. Potensi Tepung dari Ampas Industri Pengolahan Kedelai sebagai Bahan Pangan. Prosiding Seminar Nasional Kedaulatan Pangan dan Energi. Fakultas Pertanian. Universitas Trunojoyo, Madura.

\section{BIODATA}

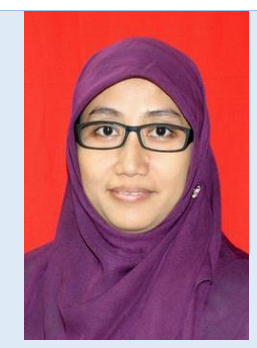

Shanti Pujilestari adalah pengajar pada Program Studi Teknologi Pangan Fakultas Teknologi Pangan dan Kesehatan Universitas Sahid Jakarta. Yang bersangkutan telah menempuh pendidikan Diploma Gizi DEPKES RI, S1 di Teknologi Pangan dan S2 di Manajemen peminatan manajemen pariwisata. Penelitian yang banyak ditekuni adalah makanan tradisional 
Niken Larasati adalah alumni Teknologi Pangan Fakultas Teknologi Pangan dan Kesehatan Universitas Sahid Jakarta. Latar belakang pendidikan diantaranya SMK Farmasi Caraka Nusantara. Saat ini yang bersangkutan bekerja sebagai QC Microbiology di PT Etana Biotechnologies Indonesia

Jurnal Teknologi Pangan dan Kesehatan (The Journal of Food Technology and Health) Memuat artikel ilmiah berupa hasil penelitian bidang teknologi pangan dan gizi

Diterbitkan oleh Fakultas Teknologi Pangan dan Kesehatan, Universitas Sahid, Jakarta Web: http://jurnal.usahid.ac.id/index.php/teknologi_pangan; E-mail: jtepakes@gmail.com 